\title{
Research on the Assessment and Evaluation of Teacher in Police Colleges
}

\author{
Xiaolei Zhang \\ Liaoning Police College \\ Dalian, Liaoning, 116036, China \\ lnjcxyzzrsc@163.com
}

\begin{abstract}
The assessment of teacher is an important issue in colleges and university, especially for personnel management of university in China. The purpose of this study is to develop an assessment system of teacher for applied police undergraduate college. This paper first analyzed the problems existing in the teacher assessment, and then discussed the basic characteristics and components of the teacher assessment system by means of comprehensive assessment and dynamic analysis, finally established the teacher assessment index system. The research shows that the effectiveness of teacher assessment depends on the correct cognition of assessment content, the reasonable selection of assessment indicators, the credibility of assessment standards and the scientificity of assessment methods.
\end{abstract}

Keywords_police colleges; teacher assessment; characteristics of assessment system; indicator system; evaluation method

\section{INTRODUCTION}

As we all know, one of the key factors to determine the quality of a university is the quality of its teachers. In fact, an important task of university personnel management department is teacher management, and the important content of teacher management is teacher assessment and evaluation. In the actual process of teacher management, first of all, we must establish a perfect assessment system, and then, to establish an effective evaluation mechanism through the operation of the assessment system. However, no matter in the early scientific management or today's modern management, the assessment and evaluation of personnel is still an unsolved management problem [1]. For example, in the performance appraisal of university teachers, what is assessed? What methods are used? How to conduct the evaluation after assessment? And so on, these problems have become a common daily work, but how to achieve the satisfactory effect of assessment and evaluation is not an easy thing. This paper studies the problem of teacher assessment and evaluation from the perspective of combining theory and practice based on the characteristics and development of teachers in public security colleges. Hope to play a guiding role in the research and practice of teacher management.

\section{PROBLEMS EXISTING IN TEACHER ASSESSMENT}

The assessment of teachers is closely related to the development of colleges and universities and the vital interests of teachers. Effective assessment can promote the realization of the development goals of colleges and universities, at the same time, it is also one of the most effective means to mobilize the enthusiasm of teachers. Otherwise, there will be injustice and dissatisfaction, reducing the enthusiasm and performance of teachers [2]. Taking police colleges as examples, this paper investigates the problems existing in teacher assessment, and the results are as follows.

\section{A. Positioning problem of assessment}

The current orientation of teacher assessment is vague, which is not combined with the orientation, development goal and educational purpose of police colleges [3]. Moreover, it is not clear what problems the teacher assessment should solve, and the assessment lacks a clear purpose. The obvious problem is that the assessment is carried out for the purpose of assessment, making the assessment a mere formality, consuming a lot of time, manpower and material resources, and the results of the assessment cannot be fully utilized.

\section{B. The problem of assessment index system}

To a large extent, the current teacher assessment still follows the indicator system of subject-oriented universities, which mainly focuses on teaching and scientific research, and takes the teaching workload, teaching quality and scientific research workload undertaken by teachers as the main assessment indicators, lacking the assessment indicators for the characteristics of public security colleges.

\section{The assessment method}

The current teacher assessment basically adopts the qualitative method, that is, relying on the subjective impression of the examiners or self-written description of the examines, failing to use statistical analysis and computer technology to improve the efficiency and effect of the assessment by means of quantitative means, so as to control the subjectivity, increase the objectivity, comparability and comprehensiveness.

\section{THE BASIC CHARACTERISTICS OF TEACHER Assessment System IN POLICE COLLEGES}

In order to establish a teacher assessment system suitable to the characteristics of police colleges, it is necessary to define the characteristics of the teacher assessment system. 


\section{A. Emphasizing the overall development goals of police colleges}

The indicators of teacher assessment should be closely combined with the development goals of the college. The assessment indicators should be formulated by referring to the development plan of the college and the responsibilities of the college teachers, which in turn evolve from the school-running purpose and orientation of the college. In this way, the development goals of the college are decomposed layer by layer, so that the development plan of the college can be implemented, and the achievement of the college's work goals can be tested by examining the performance of teachers. Therefore, the assessment system should not only pay attention to the individual professional development of teachers, but also pay attention to the promotion of the development of the college through department planning, communication and management involving department personnel. [4]

\section{B. Assessment indicators should promote each other}

For applied police undergraduate colleges, teaching is a teacher's job, but scientific research is an important factor to promote the quality of teaching. Because, teachers can bring the latest research results into textbooks and courses through scientific research, playing a role of mutual promotion between scientific research and teaching. In addition, teachers' social practice is also an important evaluation index. The participation of teachers in the practice of public security is helpful to enrich the practical knowledge in the field of public security, at the same time, it can also improve the police professional ability of teachers and better serve the actual combat department, so as to improve the popularity and credibility of the college, and improve the College's ability and level of running a College.

\section{The assessment indicators should be measurable}

The assessment indicators should be specific, that is to say, the assessment indicators should reflect the teacher's work content, and have four measurable, can be measured, can be achieved, realistic, time-limited. The so-called measurable means that each index can be quantified by mathematical methods. Achievable, that is, the indicators are teachers in the appropriate time to pay a certain amount of efforts can be achieved. Realistic, that is, the performance of teachers in various indicators can be proved and observed. Time-limited, that is, the realization of the index is time limited. Such an indicator system makes the measurement scale of teachers more objective, and makes the decision of evaluation and promotion more scientific and fair.

\section{Evaluating the efficiency of indicators}

The number of assessment indicators determines the complexity of the assessment process. In the research of system evaluation theory, how to determine the quantity of evaluation index is a difficult problem. If the number of indicators is too small, it is difficult to achieve the purpose of system evaluation; if the number of indicators is too much, it will increase the complexity of the system evaluation process, easy to produce contradictions and deviations. In general, by limiting the number of assessment indicators, the information needed to be collected can be reduced to the extent that it is easy for the examiners to operate, so as to improve the operability of the assessment, avoid occupying too much energy and attention of the examiners and examinees, and improve the efficiency of the assessment indicators.

\section{E. Continuity and continuity of the assessment process}

The assessment process includes not only the annual assessment, but also the assessment combined with the appointment system, Routine assessment and regular dialogue between teachers, department leaders and other personnel throughout the year. [5]At the same time, the assessment indicators for teachers should be dynamic and can reflect the key work of the college in different periods, and the assessment system should reflect the guidance for future work. Therefore, the assessment form is composed of three parts: selfassessment, college opinions and target plan. The target plan makes the work prospect of the next assessment period, which should be completed through consultation between teachers and examiners.

\section{F. Self-evaluation and feedback}

The assessment of police colleges should emphasize teachers' self-recognize and learning ability. It is necessary to pay attention to the feedback of the assessment results, get to know the evaluation information of colleges, departments, peers and students, so as to improve their work in the future.

\section{The Evaluation System of Teacher Assessment}

\section{A. Evaluation index of teacher assessment}

The college will establish teacher evaluation system with fair, justice, and transparent as an important part of college management. The guiding ideology of establishing teacher evaluation index must be highly consistent with the discipline attribute, talent cultivation and development goal of the college, which is the direct embodiment of the development goal of the college to the individual teachers. The evaluation index system of teacher assessment not only plays a goal-oriented role, which is conducive to the development of teachers themselves, but also can ensure the quality of talent cultivation, the level of scientific research, and the performance of public security work.

\section{B. The composition of evaluation indexes}

We set up an evaluation system composed by five first-level indicators through the analysis of the discipline characteristics, teachers' team characteristics and talent training characteristics in police colleges.

The five first-level indicators include professional ethics, teaching, scientific research, police practice, learning and selfdevelopment, and there are second-level indicators under the five first-level indicators (see table 1).

1) The teacher's professional ethics

Teachers' professional ethics: this index includes work attitude and responsibility, but it is difficult to quantify and easily affected by subjective factors. Therefore, we can choose the specific content that is easy to be quantified, such as the number of times that teachers participate in various political 
learning and activities, attend various conferences and social services, the performance of help colleagues and guide students, and teaching accident rate that reflects teachers' working attitude and responsibility, and so on.

TABLE I. EVALUATION INDEX SYSTEM OF TEACHER ASSESSMENT

\begin{tabular}{|c|c|c|c|c|}
\hline First-level indicators and weights & \multicolumn{4}{|c|}{ Second-level indicators and weights } \\
\hline $\begin{array}{c}\text { Professional ethics } \\
(0.05)\end{array}$ & $\begin{array}{l}\text { Attendance } \\
(0.025)\end{array}$ & $\begin{array}{l}\text { Teaching accident rate } \\
(0.025)\end{array}$ & & \\
\hline $\begin{array}{l}\text { Teaching } \\
(0.4)\end{array}$ & $\begin{array}{l}\text { Teaching workload } \\
(0.1)\end{array}$ & $\begin{array}{l}\text { Teaching quality } \\
(0.2)\end{array}$ & $\begin{array}{c}\text { Courses and } \\
\text { textbooks }(0.05)\end{array}$ & $\begin{array}{c}\text { Instruct } \\
\text { students(0.05) }\end{array}$ \\
\hline $\begin{array}{l}\text { Scientific research } \\
(0.3)\end{array}$ & $\begin{array}{c}\text { Research } \\
\text { workload(0.1) }\end{array}$ & $\begin{array}{c}\text { Scientific research workload } \\
\text { combined with public security } \\
\text { departments } \\
(0.1)\end{array}$ & $\begin{array}{l}\text { Scientific research } \\
\text { achievements } \\
(0.1)\end{array}$ & \\
\hline $\begin{array}{l}\text { Self-development } \\
(0.05)\end{array}$ & $\begin{array}{l}\text { Continuing education } \\
\text { hours }(0.025)\end{array}$ & $\begin{array}{c}\text { The ability to learn new } \\
\text { technologies } \\
(0.025)\end{array}$ & & \\
\hline
\end{tabular}

2) Teachers' teaching work

Teachers' teaching work: teachers' teaching workload and teaching quality are evaluated according to different types and standards. In practical evaluation, teachers can be divided into public basic course teachers, professional basic course teachers and professional course teachers, and teachers' teaching workload can be determined according to different types, disciplines and titles. In terms of teaching quality, in addition to classroom teaching quality evaluation, different assessment elements should be added according to different disciplines. For example, the teaching field includes the interaction between all teachers and students, which is not limited to classroom teaching, but also includes answering questions after class, guiding students to finish their graduation thesis. In addition, teaching activities include course design and case studies conducted with the public security department. [6]

\section{3) Teachers' police practice}

The practice of public security is a remarkable characteristic of the teachers in police colleges. Police colleges require teachers to have the quality of "double teachers". In addition to teaching theoretical knowledge, they should also understand the actual needs and development trend of public security, master the new technology in the professional field of public security, and guide students to participate in police practice.

\section{4) Teachers' scientific research}

The scientific research of police colleges is not limited to publishing papers and works, but more importantly to reflect the guiding role of research work. Teachers should be encouraged to carry out applied technical research and cooperate with public security departments in project development, so as to reflect the characteristics of applied research and produce more applied research results. Therefore, the proportion of applied research results should be increased in the determination of assessment standards for scientific research workload. We should make full use of the latest research results of public security theory and technology to serve the public security work and deal with the urgent problems to be solved. The first is to promote the transformation of scientific research results; the second is to combine scientific research with the practice of public security work. By understanding the work of public security and combining the practice of public security for teaching and scientific research, we can understand the requirements of public security departments on the quality of talents, and determine the objectives of talents cultivation, so as to achieve the coordinated development of teaching, scientific research and practice. [7]

\section{5) Teacher's self-development}

The development of police colleges is characterized by the orientation of public security work. Therefore, teachers are required to have strong ability to change and adapt, and teachers must constantly update their knowledge and master new technologies through learning and self-development. Teacher learning and self-development include two secondary indicators: continuing education hours and the ability to master new technologies

The relationship between indicators at all levels: the firstlevel indicators are closely related to the development goals of the college, and the second-level indicators are to achieve the first-level indicators, requiring teachers to do something specific. Therefore, second-level indicators are the driving factors of teacher performance. These second-level indicators clearly tell teachers what they should do in daily work and play a good goal-oriented role.

\section{Calculation method of Assessment results}

The assessment results of teachers are obtained through the comprehensive evaluation of five dimensions. The specific calculation process is as follows: first, give each first-level index and second-level index weight. Then, the quantifiable indicators are directly calculated, and qualitative indicators are scored by sampling. The weighted average scores of the items are calculated using the following formula:

$$
U=\sum_{i=1}^{m} A_{i} D_{i}+F
$$

$A_{\mathrm{i}}$ is the score of first-level index, $D_{\mathrm{i}}$ is the weight of each project, $\mathrm{m}$ is the number of first-level index, and $\mathrm{F}$ is the score of special contribution. [8] 
Computer assessment information system is adopted to make single or multiple data statistics, calculation, summary, analysis and queuing of each element in the index system. Teachers' work performance can be reflected objectively and impartially through the above calculation.

\section{CONCLUSIONS}

The teacher assessment of police colleges should be different from that of ordinary colleges and universities. We should design the assessment indicators according to the running goal, subject characteristics and industry attributes of police colleges, and the assessment indicators should reflect the orientation of colleges to teachers. In the evaluation system of teacher assessment, the emphasis is not only on teaching and scientific research, but also on teachers' police practice and selfdevelopment. The evaluation index system that can be quantified should be selected as far as possible, and statistics and analysis should be carried out by using computer information system to ensure that the evaluation can reflect the actual performance of teachers' work and form an effective goal incentive mechanism.

\section{REFERENCES}

[1] Dominik Becker, Klaus Birkelbach. Teachers' Evaluations and the Definition of the Situation in the Classroom. Cologne Graduate School in Management, Economics and Social Sciences, 2011, vol.2, pp.18-39.

[2] He Qin. The Study on Construction of Performance Appraisal for the Application- oriented University Teacher. JOURNAL OF CHANGSHA UNIVERSITY, 2005, vol. 19, pp.48-50.

[3] Wang Binhua. Research on Criterion of Teacher Evaluation. Teacher Education Research, 2009, vol. 21, pp.53-57.

[4] Chen Ying, Ji Liu, Liu Qin. Application Research of Fuzzy Theory in PE Teaching Evaluation. TELKOMNIKA, 2013, vol. 11, pp. 5133 5140.

[5] Si Futing. On Development-Oriented Evaluation of Teachers \&Professional Development of Teachers. Theory and Practice of Education. 2009, vol. 29, pp.37-39.

[6] Mao Xudong. The Study of Teacher Performance Evaluation in the University. Master of Business and Administration Business School Wuhan University, 2004.

[7] Zhang Yong, Zhang Yan. Construction of university teacher performance evaluation system from the perspective of classified development, Exploration of Higher Education, 2018, pp.97-103.

[8] Huang Yongliang. Research on the construction of university teachers' performance evaluation system based on teachers' independent development. Tribune of Theory, 2018, pp.104-110. 